\title{
KEJAHATAN TINGKAT TINGGI
}

\author{
Oleh : Yuliana Surya Galih, S.H., M.H.")
}

\begin{abstract}
ABSTRAK
Kemajuan dibidang IImu Pengetahuan dan Teknologi, membawa manusia kepada dimensi kehidupan yang modern. Intelektualitas manusia terus memakin maju. Kemajuan intelektual itu juga mempengaruhi kepada prilaku manusia, bukan hanya sekedar berprilaku baik, akan tetapi sebaliknya timbul pemikiran kotor, tamak dan jahat. Kejahatan-kejahatan yang dilakukan oleh kalangan intelektual pun muncul, sehingga timbullah apa yang disebut dengan kejahatan kerah putih (white collar crime) sebagai kebalikan dari kejahatan kerah biru (blue collar crime) atau kejahatan jalanan.

White colar crime hanya bisa dilakukan oleh orang-orang tertentu yang memiliki kemampuan (skill), dilakukan oleh orang-orang berpendidikan dan orangorang yang mempunyai status sosial yang tinggi. Kejahatan yang termasuk white collar crime sulit untuk diungkap, karena kejahatan ini berbeda dengan kejahatan konvensional, sehingga diperlukan aturan hukum, sarana dan prasarana yang memadai dan aparat penegak hukum yang handal.
\end{abstract}

\section{ABSTRACT}

Progress in Science and Technology, brings man to the dimension of modern life. Memakin human intellect continues forward. Intellectual progress it also affects the human behavior, not just behave well, but otherwise the thought dirty, greedy and evil. The crimes committed by intellectuals appeared, so that there arose the socalled white-collar crime (white collar crime) as opposed to blue collar crime (blue collar crime) or street crime.

White colar crime can only be done by certain people who have the capabilities (skills), carried out by educated people and those who have a high social status. Crimes include white collar crime is difficult to uncover, because this crime is different from conventional crime, so we need the rule of law, adequate infrastructure and reliable law enforcement officers.

\section{PENDAHULUAN}

Kemajuan IImu Pengetahuan dan

Teknologi telah mengantarkan manusia kepada kehidupan yang lebih baik, lebih mudah dan lebih cepat. Apa yang tidak pernah terbayangkan dahulu, kini menjadi kenyataan, perkembangan ilmu pengetahuan tersebut, hampir disemua sendi-sendi kehidupan, mulai dari hal- hal yang penting sampai kepada hal-hal yang bersifat hiburan (entertement). Seperti dibidang transfortasi, komunikasi, kedokteran, persenjataan dan lain sebagainya.

Penemuan dibidang teknologi membawa dampak kepada sikap dan prilaku manusia, terhadap pemanfaatan dari teknologi tersebut, pekerjaan-

\footnotetext{
*) Staf Pengajar Fakultas Hukum Universitas Galuh
} 
pekerjaan yang tadinya bersifat manual dan tradisional telah beralih kepada penggunaan yang serba mekanik, autometik dan modern.

Perkembangan ilmu pengetahuan dan teknologi memang telah berdampak yang cukup baik dan mengantarkan manusia kepada kehidupan yang lebih baik, namun disisi lain pemanfaatan teknologi yang tidak bertanggung jawab juga telah menyengsarakan umat manusia.

Teknologi persenjataan, dari waktu ke waktu terus dikembangkan untuk kepentingan perang, telah mengubah bentuk perang trandisional kepada perang modern, dengan jumlah korban yang cukup banyak, seperti penemuan dibidang senjata kimia, senjata biologis, senjata nuklir. Berakhirnya perang dunia kedua adalah bukti betapa dasyat dan mengerikan senjata nuklir, sesuatu hal yang sungguh tak terbayangkan sebelumnya, dan mengingatkan kepada umat manusia akan bahaya perang nuklir tersebut.

Pada akhirnya penemuanpenemuan dibidang ilmu pengetahuan, dimanfaatkan juga untuk melakukan kejahatan. Kejahatan-kejahatan yang dahulu masih konvensional telah beralih kepada bentuk kejahatan-kejahatan modern, dengan memanfaatkan ilmu pengetahuan dan teknologi. Kejahatankejahatan dengan memanfaatkan ilmu pengetahuan dan teknologi tersebut tidak bisa dilakukan oleh sembarang orang, namun hanya bisa dilakukan oleh orang-orang tertentu yang memiliki kemampuan intelektual tinggi yang memahami ilmu pengetahuan dan teknologi.

Kejahatan dibidang perbankan, money laundering, cybercrime, terorisme dan lain-lain adalah salah satu bentuk kejahatan-kejahatan yang hanya bisa dilakukan oleh orang-orang tertentu.

Kejahatan-kejahatan konvensional atau blue collar crime (seperti pembunuhan, penipuan, pencurian dan lain-lain), sedangkan kejahatankejahatan modern seperti tersebut di atas sering disebut dengan istilah white collar crime atau kejahatan kerah putih atau kejahatan berdasi. Dalam kejahatan konvensional yang melibatkan para pelaku kejahatan jalanan (street crime, blue collar crime), kejahatan kerah putih (white collar crime) pelakunya merupakan orang terpandang dalam masyarakat, mempunyai kedudukan atau jabatan serta mempunyai kemampuan intelektual yang tinggi, yang mengetahuai berbagai macam teori, data dan statistik dalam bidang ilmu pengetahuan tersebut. 
White collar crime seolah-olah merupakan perbuatan yang biasa dan legal, sehingga jika diukur dari canggihnya modus operandi, dilihat dari kelasnya orang yang telibt atau dilihat dari besarnya dana yang dijarah, perbuatan white collar crime jelas merupakan kejahatan kelas tinggi yang sebenarnya dilatarbelakangi oleh prinsip yang keliru, yaitu greedy is beautiful (kerakusan itu indah) (Munir Fuady, 2004 : 2).

Kejahatan dalam bentuk White collar crime, perbuatannya tidak hanya bersifat nasional, akan tetapi juga telah transnasional dan merupakan suatu jaringan atau sindikat internasional. Seperti perdagangan narkoba, penyelendupan, perdagangan manusia (trafciking), cyber dan lain-lain. Kejahatan-kejahatan tersebut penanggulangannya tidak cukup hanya bersifat nasional saja akan tetapi perlu adanya kerjasama antarnegera, diperlukan sarana dan prasarana yang memadai serta Sumber Daya Manusia yang handal, yang mampu memahami ilmu pengetahuan dan teknologi.

Berdasarkan uraian tersebut di atas, maka membahasan, dibatasi yaitu :

Apakah kejahatan tingkat tinggi dan bagaimana penanggulangannya?

\section{PEMBAHASAN}

\section{Sejarah dan pengertian White collar crime}

White collar crime diterjemahkan dalam bahasa Indonesia menjadi kejahatan kerah putih atau kejahatan berdasi. Untuk pertama kalinya white collar crime dikemukakan dan dikembangkan oleh seorang kriminolog Amerika Serikat yang bernama Edwin Hardin Stherland diawal decade 1940an, yang kemudian didalam pidato dari Sutherland yang selalu dikenang dan saat itulah pertama kali muncul konsep white collar crime, yaitu pada pidatonya tanggal $27 \quad$ Desember 1939 (J.E.Sahetapy, 1994: 1).

Konsepsi ini mendapatkan tentangan dari Paul Tappan dalam bukunya Who is the Criminal? (1947), dimana dia mengkritik pandangan Sutherland yang berakar dari pemikiran Durkheim bahwa suatu perbuatan dianggap jahat berdasarkan reaksi masyarakat. Menurutnya konsepsi white collar crime terutama perbuatannya, harus didasarkan pada hukum yang berlaku, demi kemudahan dalam pengusutan dan penuntutan. (reptarofzone.blogspot.com)

Sebelumnya, E.A. Ross pernah menyebut kejahatan ini sebagai criminaloid dimana memiliki karakter seseorang yang mencari kemakmuran 
melalui cara yang memalukan, tetapi tidak dianggap melanggar oleh masyarakat dan masyarakat tidak menggolongkan mereka sebagai penjahat. (reptarofzone.blogspot.com)

A. Morris menggunakan istilah criminal of the upper world untuk menunjukkan kejahatan dengan ciri pelaku yang tidak teridentifikasi dengan jelas, dimana dengan posisinya, kemampuannya, dan kepintarannya memungkinkan untuk berbaur dengan orang lain sehingga tidak digolongkan sebagai penjahat.

(reptarofzone.blogspot.com)

Penelitian selanjutnya telah mengembangkan konsep white collar crime, bukan hanya dilakukan oleh individual tetapi dapat pula dilakukan oleh organisasi. Seperti studi yang dilakukan oleh Clinard (1946) terhadap perilaku pelanggaran yang dilakukan oleh perusahaan bisnis saat Perang Dunia II, Hartung (1950) terhadap industri daging di Detroit, Quinney (1963) terhadap pelanggaran yang dilakukan toko obat/ apotik, dan Geis (1967) terhadap pelanggaran anti monopoli yang dilakukan oleh perusahaan listrik.

(reptarofzone.blogspot.com)

$$
\text { Edelhertz }
$$

mendefinisikan white collar crime sebagai perbuatan atau serangkaian perbuatan ilegal yang dilakukan secara non fisik dan dengan sembunyisembunyi atau tipu muslihat, untuk mendapatkan uang atau barang, untuk menghindari pembayaran atau kehilangan uang atau barang, atau untuk mendapatkan keuntungan bagi perusahaan maupun bagi diri sendiri. (Munir Fuady, 2004:12)

Dictionary of Criminal Justice Data Terminology mendefinisikan white collar crime sebagai nonviolent crime dengan tujuan untuk mendapatkan keuntungan finansial yang dilakukan dengan menipu, oleh orang yang memiliki status pekerjaan sebagai pengusaha, profesional atau semi profesional dan menggunakan kemampuan teknis serta kesempatan atas dasar pekerjaannya. Atau perbuatan dengan tujuan untuk mendapatkan keuntungan finansial, menggunakan tipu muslihat dan dilakukan oleh orang yang memiliki kecakapan khusus dan pengetahuan profesional atas perusahaan dan pemerintahan, terlepas dari pekerjaan tersebut. (munir Fuady, 2004:12).

Beberapa pengertian white collar crime, telah menunjukan bahwa ada perbedaan yang cukup jelas antara kejahatan konvensional dengan kejahatan modern, perbedaan tersebut bukan saja dilihat dari pelaku 
kejahatannya, akan tetapi modus serta alat yang dipergunakan untuk mewujudkan kejahatan itu sendiri berbeda dengan kejahatan konvensional.

\section{Karakteristik white collar crime}

Pelaku kejahatan modern atau white collar crime, memiliki karakteristik yang berbeda dengan kejahatankejahatan konvensional, pada umumnya kejahatan konvensional tidak membutuhkan IImu Pengetahuan yang ber-hubungan dengan kejahatannya, dapat dilakukan oleh siapa saja, lebih mengutamakan kontak fisik dan lain-lain. Sedangkan beberapa karakteristik dari white collar crime antara lain : (reptarofzone. blogspot. com)

1. Pelaku sulit diidentifikasi. Jika kerusakan belum dirasakan maka korban tidak akan sadar

2. Diperlukan waktu yang lama untuk pembuktian dan juga butuh keahlian tertentu.

3. Jika menyangkut organisasi, susah dicari seseorang yang bertanggung jawab, biasanya diarahkan ke atasan karena tidak mencegah, atau kepada bawahan karena tidak mengikuti perintah atasan.

4. Proses viktimisasi juga tersamar karena pelaku dan korban tidak secara langsung berhadapan.
5. Kerumitan dan tersamarnya pelaku membuat sulit dilacak.

6. Sulit mengadili karena minimnya bukti dan siapa yang disalahkan.

7. Pelaku biasanya mendapatkan treatment atau sanksi yang ringan.

8. Pelaku biasanya mendapatkan status kriminal yang ambigu.

Menurut Vito dan Holmes karakter white collar crime, antara lain yaitu : (reptarofzone. blogspot. com)

1. Kerugian yang diderita lebih besar dibandingkan street crime.

2. Tidak selalu nonviolent.

3. Lebih rumit dalam metode yang digunakan dan kerugian yang diderita.

4. Korban lebih menderita dan penderitaan tersebut tidak dirasakan seketika.

5. Korban terutama dalam kasus simpan-pinjam, akan berkurang kepercayaannya terhadap ekonomi bebas dan pimpinan perusahaan.

6. Bisa membawa akibat penundaan/hilangnya investasi yang dilakukan masyarakat.

7. Membawa akibat pada hilangnya kepercayaan publik terhadap institusi politik, proses politik dan para pemimpin serta erosi atas moralitas masyarakat. 
8. Dalam kebijakan publik, perbedaan antara organized dan white collar crime tidak jelas.

9. Masyarakat akan menuntut penegakan hukum dan hukuman terhadap pelaku lebih keras lagi.

Jo Ann Miller, seorang kriminolog

dari Purdue University merinci pengkategorian white collar crime menjadi 4 (empat) jenis, yaitu : (reptarofzone.blogspot.com)

1. Organizational Occupational crime (Kejahatan yang dilakukan oleh organisasi atau perusahaan).

2. Government Occupational Crime (Kejahatan yang dilakukan oleh pemerintah atau atas nama pemerintah).

3. Professional Occupational crime (Kejahatan yang berkenaan dengan profesi).

4. Individual Occupational Crime (Kejahatan yang dilakukan secara individu).

Bloch dan Geis membagi white collar crime dalam 5 (lima) bagian, yaitu : (reptarofzone.blogspot.com)

1. Sebagai individual (dilakukan oleh profesional seperti pengacara, dokter).

2. Pekerja terhadap perusahaan atau bisnis (contohnya korupsi).
3. Petugas pembuat kebijakan untuk perusahaan (contohnya dalam kasus anti monopoli)

4. Pekerja perusahaan terhadap masyarakat umum (contohnya penipuan iklan)

5. Pelaku bisnis terhadap konsumennya (contohnya penipuan konsumen).

Apabila melihat karekteristik white collar crime tersebut di atas, suatu perbuatan dapat dikualifikasikan sebagai white collar crime apabila memenuhi unsur-unsur sebagai berikut : (ejurnal.esaunggul.ac.id)

1. Dengan sengaja melakukan perbuatan melawan hukum

2. Merugikan Masyarakat dan atau Negara

3. Dilarang oleh aturan hukum pidana

4. Perbuatannya diancam dengan pidana

5. Dilakukan oleh orang-orang tertentu Dalam suatu perbuatan pidana maka unsur dengan sengaja (opzettelijk) melakukan perbuatan melawan hukum (wederrechtelijk) adalah unsur pokok, adanya unsur dengan sengaja ini, untuk menentukan bahwa perbuatan yang dilarang itu telah dengan sengaja, disadari dan diinsyapi akibat dari perbuatan tersebut dikehendaki oleh si pembuatnya, secara melawan hukum. 
Merugikan masyarakat atau dapat merugikan keuangan negara.

Pada umumnya hampir semua tindak pidana merugikan masyarakat dan meresahkan masyarakat. Dalam tindak pidana penipuan, pencurian dan lainlain, pada umumnya kerugian yang diderita oleh korban atas tindak pidana itu bisa orang secara pribadi, bisa juga suatu badan hukum, seperti misalnya perusahaan. Akan tetapi kerugian didalam white collar crime, lebih luas lagi, yaitu masyarakat pada umumnya, seperti tindak pidana pembobolan bank, dimana bank sebagai lembaga keuangan yang menyimpan uang nasabah, dibobol oleh seseorang sehingga uang nasabah tersebut hilang.

Kerugian keuangan negara, yang paling jelas dalam white collar crime adalah tindak pidana korupsi. Pada umumnya tindak pidana korupsi adalah mengambil uang negara secara melawan hukum, baik bertujuan untuk menguntungkan diri sendiri maupun orang lain. Tindak pidana korupsi, hanya bisa dilakukan oleh orang-orang tertentu yang berhubungan baik secara langsung maupun tidak langsung dengan keuangan negara, yang kepadanya diberikan suatu kewenganan atau menduduki suatu jabatan tertentu. Sehingga tindak pidana korupsi termasuk juga salah satu jenis white collar crime.

Perbuatan itu dilarang oleh hukum pidana, serta atas perbuatan tersebut diancam dengan hukum pidana. Undang-undang telah menentukan perbuatan-perbuatan apa saja yang dilarang, dan pelanggaran atas ketentuan undang-undang tersebut diancam dengan hukum pidana. Pemalsuan surat misalnya, didalam KUHP sudah jelas diatur. Tidak semua orang bisa melakukan perbuatan memalsukan surat, hanya orang-orang yang mempunyai keahlian dan intelektual saja bisa melakukan perbuatan pemalsuan tersebut.

Perbedaan utama antara white collar crime dan tindak pidana biasa antara lain terletak pada pelakunya dan penggunaan harta hasil kejahatan yang dilakukan serta cara kerjanya. Pelaku pada kejahatan yang tergolong white collar crime dilakukan oleh orang yang memiliki intelektual dan terkait dengan pengaruh kekuasaan, jabatan serta keuangan dan dengan pengaruh tersebut mereka lantas beranggapan bahwa "mereka kebal terhadap hukum, dan cemooh masyarakat, anggapan demikian karena mereka merasa hukum itu dapat "dibeli". Banyak kasus-kasus tindak pidana korupsi, pelakunya masih bisa menjalani hidup enak. Misalnya 
Gayus Tambunan, yang kedapatan melihat pertandingan sepakbola padahal dia sedang menjalani pemidanaan atau Artalyta Suryani alias Ayin yang mendapat fasilitas hotel berbintang lima di Rutan Pondok Jambu.

Pada tindak pidana biasa "pelakunya tidak tergolong kelompok intelektual mereka termasuk orang kebanyakan yang tidak memiliki jabatan tertentu dalam pemerintahan maupun dalam badan usaha. Penggunaan hasil kejahatan yang termasuk white collar crime biasanya dipergunakan untuk memenuhi kebutuhan sekunder seperti, mobil mewah, rumah mewah membeli barang-barang lux, investasi tanah, disimpan diBank dalam negeri maupun luar negeri, dan lain-lain. Sedang pada kejahatan biasa hasil yang diperoleh biasanya hanya sekedar untuk memenuhi kebutuhan primer seperti makan, minum, serta kebutuhan biologis lainnya. (ejurnal.esaunggul.ac.id)

\section{Kesulitan-kesulitan dalam Penegakan Hukum dalam Kasus White Collar Crime}

Kejahatan merupakan bagian dari perkembangan masyarakat. Kehidupan dinamika masyarakat yang terus berkembang membawa dampak kepada munculnya berbagai macam bentuk kejahatan, dengan "varian-varian baru".

Ketika transaksi keuangan masih bersifat manual, belum ada mesin ATM, belum ada jaringan internet, seorang nasabah akan mengambil uang langsung ke bank, resiko terbesar dari mengambil uang ke bank, adalah tindak pidana pencurian, yang sifat kejahatannya adalah adanya kontak fisik antara pelaku dengan korban, dimana pelaku akan memaksa dengan berbagai macam cara baik tanpa menggunakan kekerasan maupun menggunakan kekerasan kepada korban untuk menyerahkan uangnya.

Namun seiring dengan kemajuan dibidang perbankan dengan memanfaatkan kemajuan Teknologi Informasi, seseorang bisa mengambil uang nasabah dari suatu bank, hanya dengan duduk manis dihadapan komputer, dan menekan-nekan tombol keyboard memasukan kode-kode tertentu, dalam sekejap uang seorang nasabah akan beralih ke rekening tertentu sesuai dengan kode-kode yang dituliskan tadi. Dalam kejahatan seperti itu, akan sulit untuk menelusuri siapa pelakunya dan dimana dia melakukan tindak pidananya, sebab kejahatankejahatan dengan memanfaatkan teknologi informasi bisa dilakukan 
dimana saja, tanpa batas-batas yurisdiksi suatu negara.

Kesulitan didalam mengungkap kasus-kasus white collar crime, bukan saja kesulitan didalam masalah locus deliciti, sebagaimana tersebut di atas, kesulitan didalam mengungkap dan menganggulangi white collar crime, bukan saja harus tersedianya instrument-instrumen hukum, akan tetapi perlu juga adanya komitmen yang tegas terhadap penegakan hukum (low enforcement), disamping itu pula diperlukan sumber daya manusia yang handal, mempunyai pengetahuan yang luas tentang jenis white collar crime yang dilakukan dan yang lebih penting tidak korup.(Munir Fuady, 2004:179)

Bahwa adanya kecenderungan aparat penegak hukum lebih korup didalam penanganan white collar crime, disebabkan karena pada umumnya kejahatan white collar crime melibatkan bisnis milyaran.

Disamping itu, dalam hal penanggulangan kejahatan white collar crime, untuk dapat dibawa sampai ke pengadilan tidaklah mudah, kenyataan menunjukan bahwa membawa kasus white collar crime sampai ke pengadilan jauh lebih sulit daripada membawa kasus-kasus konvensional, kesulitan itu disebabkan oleh beberapa faktor, yaitu : (Munir Fuady, 2004:179)
1. Modus operandi dari white collar crime jauh lebih kompleks dibandingkan dengan kejahatan konvensional.

2. Pelaku white collar crime jarang yang mempunyai riwayat criminal seperti yang pada umumnya dimiliki oleh penjahat konvensional.

3. Kerugian bagi korban dari white collar crime tidak sejelas kerugian sebagai akibat dari kejahatan konvensional. Dalam kejahatan konvensional kerugian misalnya terbunuh atau lukanya korban, jadi sangat jelas kelihatan.

4. Penampilan pihak tersangka white collar crime di pengadilan umumnya seperti orang-orang innocent, tidak kelihatan seperti penjahat.

5. Karena pelaku white collar crime umumnya merupakan orang terdidik, maka dia pintar merekayasa dan menyembunyikan kesalahannya.

6. Karena pelaku white collar crime umumnya orang-orang terpandang dan memiliki banyak teman dan uang, maka dia dapat menyewa pengacara mahal dan handal yang dapat membebaskan dia dari jerat hukuman.

7. Karena pelaku white collar crime umumnya orang terpandang dan memiliki banak teman dan uang, 
maka tidak terlalu sulit baginya untuk mendekati para penegak hukum, seperti polisi, jaksa atau hakim diseluruh tingkat peradilan.

\section{Pencegahan dan Penggulangan white Collar Crime}

White Collar Crime sebagai bentuk kejahatan tingkat tinggi, dengan memanfaatkan kemajuan ilmu pengetahuan dan teknologi, sulit untuk dicegah dan ditanggulangi, karena sesuai dengan karakterisiknya tersebut. Namun sesulit apapun bentuk-bentuk dan jenis-jenis kejahatan harus diberantas dan dicegah agar tidak menimbulkan kerugian yang cukup besar bagi masyarakat pada umumnya.

$$
\text { Kebijakan penaggulangan }
$$

kejahatan atau yang biasa disebut dengan istilah "politik kriminal" dapat meliputi ruang lingkup yang cukup luas. Menurut G. Peter Hoefnagels upaya penanggulangan kejahatan dapat ditempuh dengan cara sebagai berikut : (stisiprappang. blogspot.com)

1. Penerapan Hukum Pidana (criminal law application)

2. Pencegahan tanpa pidana (prevention without punishment)

3. Mempengaruhi pandangan masyarakat mengenai kejahatan dan pemidanaan lewat mass media (influencing views of society on crime and punishment/mass media)

$$
\text { Penanggulangan }
$$

kejahatan secara garis besar dapat dibagi dua, yaitu :

- Penggulangan melalui "penal" (hukum pidana).

- Penggulangan melalui "non penal" (bukan/diluar hukum pidana).

Dalam pembagian GP. Hoefnagels tersebut diatas upaya-upaya yang disebut dalam (2) dan (3) dapat dimasukkan dalam kelompok upaya non penal. Penanggulangan kejahatan melalui jalur penal lebih menitikberatkan pada sifat represif sesudah kejahatan terjadi, sedangkan melalui jalur non penal lebih menitikberatkan pada sifat preventif sebelum kejahatan terjadi.

Penerapan Hukum Pidana, dalam konteks white collar crime, tidak bisa dilakukan pendekatan Hukum Pidana konvensional, yang banyak diatur didalam KUHP, untuk itu diperlukan pembaharuan hukum, yang bias menjangkau kejahatan white collar crime. Beberapa aturan dalam Hukum Positif Indonesia telah mengalami kemajuan yang, dengan diundangkannya berbagai aturan hukum yang mengatur terhadap kejahatankejahatan yang termasuk kedalam white collar crime. 
Beberapa undang-undang yang didalamnya mengatur kejahatan yang termasuk white collar crime, antara lain :

1. Undang-undang Nomor 31 tahun 1999 tentang tindak pidana korupsi yang telah ditambah dan diubah dengan undang-undang No. 21 tahun 2001

2. Undang-undang Nomor 15 tahun 2002 tentang Tindak Pidana Pencucian Uang (Money Laundering).

3. Undang-undang Nomor 7 tahun 1992 jo Undang-undang Nomor 10 tahun 1998 tentang Perbankan.

4. Undang-undang Nomor 5 tahun 1999 tentang Larangan Monopoli dan Persaidangan Usaha Tidak Sehat.

5. Undang-undang Nomor 11 tahun 2008 tentang Informasi dan Transaksi Elektronik.

Selain diperlukannya aturan hukum yang tegas dan jelas tentang kejahatan-kejahatan yang termasuk dalam white collar crime, diperlukan juga sarana dan prasarana, yang mendukung untuk mengungkapan kasus white collar crime. Kemudian selain aturan hukum dan sarana prasarana, yang lebih penting adalah sumber daya manusia dari aparat penegak hukum itu sendiri. Diperlukan aparat penegak hukum yang mampu mengungkap kasus-kasus white collar crime, dengan menggunakan cara-cara yang modern.

White collar crime, adalah suatu kejahatan dengan kecerdasan yang tinggi, sehingga diperlukan juga aparat penegak hukum yang lebih cerdas, tidak hanya cukup memahami masalah hukumnya saja akan tetapi juga harus memahami kejahatan itu dibidang apa, seperti misalnya kejahatan yang menyangkut bidang perbankan dan bisnis, maka aparat penegak hukumnya pun baik Penyidik, Penuntut Umum maupun hakim harus mampu menguasai bidang perbankan, bisnis dan ekonomi, sehingga tidak hanya mengandalkan keterangan ahli saja.

Perkembangan white collar crime sudah sedemikian rupa, sedangkan aparat penegak hukumnya belum mumpuni untuk mengungkap kasuskasus white collar crime, hal ini dikarenakan keterbatasan sumber daya manusia dari aparat penegak hukum itu sendiri.

Pencegahan non penal, berkaitan dengan kesadaran hukum masyarakat. Kesadaran hukum yang masih rendah mengakibatkan timbulnya angka kejahatan dan korban kejahatan. Beberapa kasus yang pernah menjadi sorotan yang berkaitan dengan kejahatan yang dikualifikasikan sebagai white collar crime pernah terjadi di tahun 
2002, adalah kasus PT. QSAR (PT. Qurma Subur Alam Raya) yang bergerak agrobisnis, menawarkan kepada masyarakat untuk berinvestasi di PT QSAR tersebut berupa uang tunai dengan paket investasi Rp. 20.000.000,00 (dua puluh juga rupiah) atau paket invenstasi ternak sapa sebesar Rp. 50.000.000,00 (lima puluh juga rupiah), keuntungan yang didapat bagi investor adalah 40\% sampai dengan $50 \%$ pertahun yang akan dibayarkan setiap bulannya.

Dalam kasus PT. QSAR tersebut, masyarakat diiming-imingi keuntungan yang cukup besar, tanpa melakukan pekerjaan. Masyarakat diberi mimpi dengan keuntungan tersebut, tanpa berpikir secara rasional, dan logika berpikir yang cerdas, padahal banyak diantara investor tersebut adalah orangorang kaya yang berpendidikan tinggi.

Kasus PT. QSAR yang pernah terjadi, kasus-kasus yang berkedok invenstasi dengan keuntungan yang cukup besar, beberapa tahun belakangan pernah terjadi juga dan korbannya adalah orang-orang kaya dan orang-orang berpendidikan.

Kasus white collar crime dibidang pendidikan, beberapa waktu lalu telah terjadi yaitu wisuda llegal oleh empat perguruan tinggi swasta (STKIP Suluh Bangsa, STT Telematika, SIT) dalam lingkup Yayasan Aldiana di Universitas Terbuka Convention Centre (UTCC), Pondok Cabe, Jakarta Selatan. Ketua Tim Evaluasi Kinerja Perguruan Tinggi Kementerian Ristek Dikti Prof. Dr. Supriadi Rustad menangkap basah wisuda illegal, tersebut, yang diikuti oleh sekitar 1200 orang. (www.beritateratas. coms berita`Nasional).

Perguruan Tinggi tersebut tidak terdaftar di Pangkalan Data Perguruan Tinggi, demikian pula mahasiswanya tidak mempunyai Nomor. Induk Mahasiswa, bahkan kampusnyapun tidak jelas keberadaannya dimana. Hanya dengan waktu beberapa bulan belajar dengan membayar uang puluhan juta rupiah mahasiswa bisa memperoleh Gelar S1 dalam waktu beberapa singkat. Dalam Kasus-kasus tersebut ada tindak pidana penipuan baik yang bermodus investasi maupun bermodus pendidikan.

Sebagian masyarakat Indonesia mempunyai kecenderungan ingin memperoleh hasil dengan cara mudah, tanpa melalui proses sebagaimana mestinya, dengan pengenyampingkan rasionalitas dan logika berpikir yang cerdas yang akhirnya jadilah korban dari kejahatan.

Korban investasi bodong, korban Mafia Perguruan Tinggi, sebenarnya bukanlah orang-orang yang tingkat 
pendidikannya rendah, korban investasi bodong, banyak diantaranya adalah orang-orang berpendidikan dan orang kaya, demikian pula dengan korban mafia Perguruan Tinggi, untuk memasuki ke Perguruan Tinggi, para mahasiswa harus lulus Sekolah Menegah Atas, namun pertanyaannya adalah mengapa mereka masih bisa tertipu.

Dari kasus-kasus tersebut di atas sebenarnya bukan saja pelaku yang berusaha dengan memberikan janji-janji dan cara-cara mudah untuk mencapai hasil tanpa melalui proses, namun juga korban sendiri sudah tidak lagi menggunakan cara berpikir realistis, cara berpikir rasional dengan menggunakan logika.

\section{KESIMPULAN}

White collar crime adalah bentuk kejahatan, yang hanya bias dilakukan oleh orang-orang tertentu yang mempunyai intelektual dan keahlian tertentu, akan tetapi intelektualitas dan keahlian tersebut dipergunakan untuk melakukan tindak pidana.

Mengungkap kasus-kasus white collar crime tidak mudah, karena white collar crime memiliki karekteristik tertentu yang berbeda dengan kejahatan-kejahatan konvensional atau kejahatan jalanan. Beberapa karekteristik tersebut antara lain antara pelaku dengan korban tidak terjadi kontak fisik secara langsung, pelaku mempunyai pendidikan yang cukup tinggi dan biasanya ahli dalam suatu bidang tertentu, kerugian yang diderita tidak secara langsung dirasakan oleh korban dan beberapa karakteristik lainnya.

Penanggulangan dan pencegahan kasus-kasus white collar crime, pada pokoknya sama dengan kejahatan-kejahatan konvensional yaitu melalui jalur penal dan non penal, akan tetapi didalam white collar crime yang, pendekatan hukum yang harus dilakukan adalah pendekatan hukum modern, yaitu perlu adanya perangkat hukum yang terbaru yang menjangkau kejahatan-kejahatan yang masuk dalam kualifikasi white collar crime, disamping itu juga diperlukan aparat hukum yang lebih handal dan menguasai suatu bidang tertentu sesuai dengan modus kejahatan white collar crime itu sendiri.

\section{DAFTAR PUSTAKA}

\section{Buku :}

Fuady, Munir, Bisnis Kotor Anatomi Kejahatan Kerah Putih, Citra Aditya Bakti, Bandung, 2004.

Nawawi Arief, Barda, Kapita Selekta Hukum Pidana, Citra Aditya Bhakti, Bandung, 2003. 
W. Pranoto, Suhartono, Bandit Berdasi Korupsi Berjamaah, Kanisius, Yogyakarta, 2008.

Sahetapy,J.E, Kejahatan Korporasi, PT.Erisco, Bandung, 1994.

Internet :

https://djicom.wordpress.com, diakses tanggal 12 Oktober 2015.

stisiprappang.blogspot.com, diakses tanggal 12 Oktober 2015.

ejurnal.esaunggul.ac.id, diakses tanggal 10 Oktober 2015.

reptarofzone.blogspot.com, diakses tanggal 15 Oktober 2015.

www.beritateratas.com, diakses tanggal 16 Oktober 2015. 